\title{
ENGINEERING PROPERTIES OF GYPSUM COMPOSITE CONTAINING CHROME TANNED LEATHER SHAVING WASTE
}

\author{
M. I. Morsy ${ }^{1}$ and A. I. Nasr ${ }^{2}$
}

\begin{abstract}
Leather tanning industry produces large amounts of solid wastes. Chrome tanned leather shaving waste (CTLS) is about $20 \%$ of these solid wastes, which has not been utilized in Egypt and causing environmental hazards and economic loss. This current work investigates the properties of new gypsum composite materials containing different percentages of CTLS, ranging between $0 \%$ and $25 \%$. The physical-mechanical characteristics for prepared composites were determined and the construction morphology was analyzed by scanning electron microscopy (SEM). The experimental results show that significant reductions of composite density (from 2.1 to $1.35 \mathrm{t} / \mathrm{m}^{3}$ ), compressive strength (from 7.0 to $2.7 \mathrm{MPa}$ ), flexural strength (from 4.5 to $2.2 \mathrm{MPa}$ ) and thermal conductivity (from 0.60 to $0.19 \mathrm{~W} / \mathrm{m}^{\circ} \mathrm{C}$ ) occurred with increasing CTLS content (from 0 to 25\%), respectively. Thermal conductivity of CTLS-gypsum composite especially at high content of CTLS allowed us to use this formulation as a separations or filling materials in buildings to increase the thermal insulation. SEM micrograph of the CTLS-gypsum composite shows homogeneous and complex structures with good interaction between CTLS and gypsum.
\end{abstract}

Keyword: leather tanning, shaving waste, gypsum composite

\section{INTRODUCTION}

$\mathrm{U}$

ndoubtedly, sustainability is the process of maintaining change in a balanced environment, in which the exploitation of resources, the direction of investments, the orientation of technological development and institutional change are all in harmony and enhance both current and future potential to meet human needs and aspirations (Giovannoni and Fabietti, 2013).

1. Agriculture Engineering department, Faculty of Agriculture, Alexandria University, Egypt.

2. Wool Production and Technology, Desert Research Center, Cairo, Egypt. 
Therefore, sustainability is becoming an increasingly important issue in the leather industry. Modern, future oriented leather production must bring economic interests, ecological soundness, and consumer benefit into line (Gudro, 2011). Raw hides and skins are from the byproducts of animals, while it is achieving now high economic value of animal production when tanned and transformed into wide leather products (Husen, et al. 2016). Leather tanning and environment are two sides of the coin. It employs a huge quantity of water and inorganic and organic chemicals for processing and thereby discharges solid and liquid wastes into the environment (Gudro, 2011).

The processing of one metric ton of raw hide or skin provides $200 \mathrm{~kg}$ of a leather final product, along with $250 \mathrm{~kg}$ of non-tanned waste, $200 \mathrm{~kg}$ of tanned waste, and $50 \mathrm{~m}^{3}$ volume of wastewater. Thus, only $20 \%$ of the raw material weight is converted to leather (Kolomaznik et al., 2003). The World Bank reported that solid wastes can represent up to $70 \%$ of the wet weight of the original hides (Bank, 1999). Worldwide chromium based tanning process is predominantly followed due to versatility of chromium (Agrawal and Kumar, 2006).

Chrome tanned leather shaving waste (CTLS) is from potential solid wastes generated from leather industry, which is small and thin pieces of leather formed during shaving operation during tanning stage of leather tanning process (Figure 1). It is being done to achieve the desired thickness for various end uses of the leather. CTLS is a chromium crosslinked protein collagen that contains higher amount of protein (Saravanabhavan et al., 2005). Thus, it is a fibrous matter containing $30-40 \%$ moisture content and about $4 \%$ of chromium oxide content (Tahiri et al., 2007).

Unsafely disposing of CTLS causes environmental impacts due to their toxicity and/or contains carcinogenic elements. In Egypt, CTLS is still disposed by incineration or landfilling, which causes an environmental hazards and economic loss. Unfortunately, there are no reliable data for produced CTLS in Egypt, while according to leather production of FAOSTAT (2017) the annual amounts of CTLS could be estimated about 25 thousand tons/year. 
Utilization of waste and biomass resources for developing new bio based composite materials has been attracting much attention by the environmentalists and socio economists. Generated CTLS from tanning process are unavoidable and valorizing it by transforming to eco-friendly materials, can be used in other useful proposes, is the main goal of previous investigations. There are several treatment methods or systems that have been attempted by researchers around the world, and they are broadly classified into (I) direct use such as making leather boards, (II) different treatment processes such as producing energy and protein hydrolysate, and (III) utilization for producing added value products such as producing ceramic pigment, composites, animal feed and tissue engineering (Pati et al., 2014).

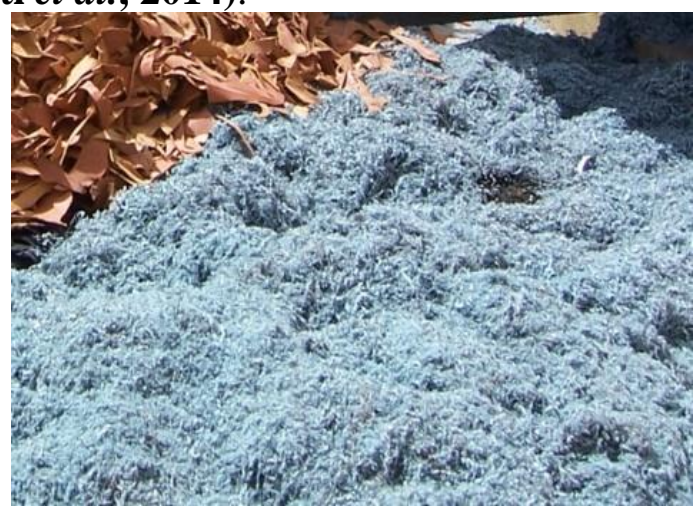

Fig.1. Chrome tanned leather shaving (CTLS).

One of these useful proposes is producing a composite from leather wastes. Composite may be defined as a material made up of two or more components and consisting of two or more phases. Such material must be heterogeneous at least on a microscopic scale. There are many reasons for using leather fiber-polymer composite materials rather than the simpler homogeneous polymers. Some of these reasons are increased stiffness, strength, dimensional stability, toughness or impact strength and vulcanized properties (Eylem and Pere, 2017 and Ponsubbiah et al., 2018).

Therefore, the main objective of this study is using CTLS in producing gypsum board to decrease its environmental impact and make it as valuable materials at the same time, as well as, improving the physical properties of gypsum board. 


\section{MATERIALS AND METHODS}

This work was carried out to develop an eco-friendly composite material of gypsum with CTLS.

\section{Materials}

The materials used for this research are locally available, which illustrated as follow:

\subsection{Gypsum}

It was used as the base binder material. The main component of gypsum is $95 \%$ calcium sulfate semi hydrate $\left(\mathrm{CaSO}_{4} .0 .5 \mathrm{H}_{2} \mathrm{O}\right)$. The gypsum was obtained from Sinai Gypsum Factory. The chemical composition of gypsum slag was measured by X-ray fluorescence technique at the Faculty of Science laboratory, Alexandria University. The results are given in Table (1).

Table 1: Constituent composition of gypsum

\begin{tabular}{ccccccccc}
\hline $\begin{array}{c}\text { Composition } \\
\%\end{array}$ & $\mathrm{Fe}_{2} \mathrm{O}_{3}$ & $\mathrm{SiO}_{2}$ & $\mathrm{CaO}$ & $\mathrm{Al}_{2} \mathrm{O}_{3}$ & $\mathrm{MgO}$ & $\mathrm{SO}_{3}$ & $\mathrm{Na}_{2} \mathrm{O}$ & Traces \\
\hline Gypsum & 0.04 & 0.23 & 32.7 & 0.09 & 0.42 & 43.68 & 0.03 & 22.81 \\
\hline
\end{tabular}

\subsection{Chrome tanned leather shaving (CTLS)}

It used in this study were collected from El-Shafei Sons tannery, located in Alexandria, Egypt. Collected CTLS was dried for five days in an open shaded place without using any thermal drying treatment. Chemical characterization of CTLS was determined. Moisture, sieve analyses, density, ash, fat, protein, chrome contents and $\mathrm{pH}$ values of CTLS were determined according to American Standard Testing Method (ASTM, 2014).

\subsection{Water}

A clean tap water was used for these experiments.

\section{Methods}

\subsection{Specimen preparation:}

Different proportions of CTLS were mixed with gypsum and water by hand to form $0,5,10,15,20$ and $25 \%$ of CTLS-gypsum solid composite as described in Table (2). Before mixing for each mixture, the amount of mixing water was estimated experimentally to obtain a homogeneous mixture of good workability. New mixtures were then done by adding the 
exact water volume. Dimensions of experimental specimens were $20 \mathrm{~cm}$ $\times 20 \mathrm{~cm} \times 4 \mathrm{~cm}$ for thermal conductivity test and $16 \mathrm{~cm} \times 4 \mathrm{~cm} \times 4 \mathrm{~cm}$ for physico-mechanical tests, which were prepared by filing the mixture into wooden moulds. They were left for one day at room temperature. Samples were then removed and kept in room condition until the weight was fixed.

\subsection{Experimental procedures:}

\subsubsection{Mechanical properties tests}

According to European Standard (DIN EN 196-1), specimens of dimensions $16 \mathrm{~cm} \times 4 \mathrm{~cm} \times 4 \mathrm{~cm}$ were used to determine the mechanical properties after keeping them in room conditions for 1, 7 and 28 days.

The three-point flexural strength test was determined out on three prismatic specimens and then a compressive strength test was conducted on six pieces of prisms. Compressive and flexural strength were calculated using equations (1) and (2) as follows:

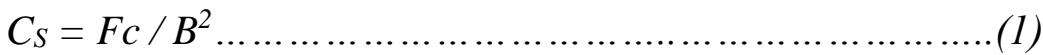

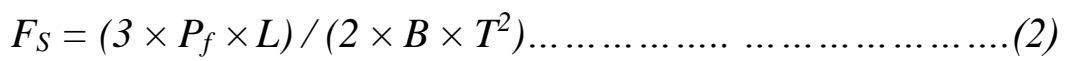

Where, $C_{S}$ is the compression strength $(\mathrm{MPa}), F_{C}$ is the compressive failure load $(\mathrm{N}), F_{S}$ is the flexural strength $(\mathrm{MPa}), P_{f}$ is the flexural failure load $(\mathrm{N}), L$ is the length of sample $(\mathrm{mm}), B$ is width of the sample $(\mathrm{mm})$, and $T$ is thickness of the sample (mm).

Table 2: Proportions of different gypsum mixture composites

\begin{tabular}{cccc}
\hline Mixture & Gypsum, $\mathbf{g}$ & CTLS, $\mathbf{g}$ & Water, $\mathbf{g}$ \\
\hline Mixture 100 & 1000 & 0 & 400 \\
Mixture 95 & 950 & 50 & 430 \\
Mixture 90 & 900 & 100 & 460 \\
Mixture 85 & 850 & 150 & 490 \\
Mixture 80 & 800 & 200 & 520 \\
Mixture 75 & 750 & 250 & 550 \\
\hline
\end{tabular}

\subsubsection{Thermal conductivity test:}

Thermal conductivity test was done based on steady-state heat transfer mode. The measuring system is shown in Figure (2). The specimen was placed between a hot plate and a cold plate. Temperatures of the two 
plates were automatically controlled, while the temperatures of each face of the sample were monitored by thermocouples. The thermal conductivity was calculated using Fourier's law equation (3) as follow:

$$
K=(Q \times T) /\left[\left(T_{h}-T_{c}\right) \times A\right]
$$

Where, $K$ is the thermal conductivity $\left(\mathrm{W} / \mathrm{m} .{ }^{\circ} \mathrm{K}\right), Q$ is the steady state conducted heat transfer across the sample $(\mathrm{J} / \mathrm{sec}), T$ is the sample thickness (m), $T_{h}$ is temperature of the hot plate $\left({ }^{\circ} \mathrm{K}\right), T_{c}$ is temperature of the cold plate $\left({ }^{\circ} \mathrm{K}\right)$, and $A$ is the heat transfer area of the sample $\left(\mathrm{m}_{2}\right)$.

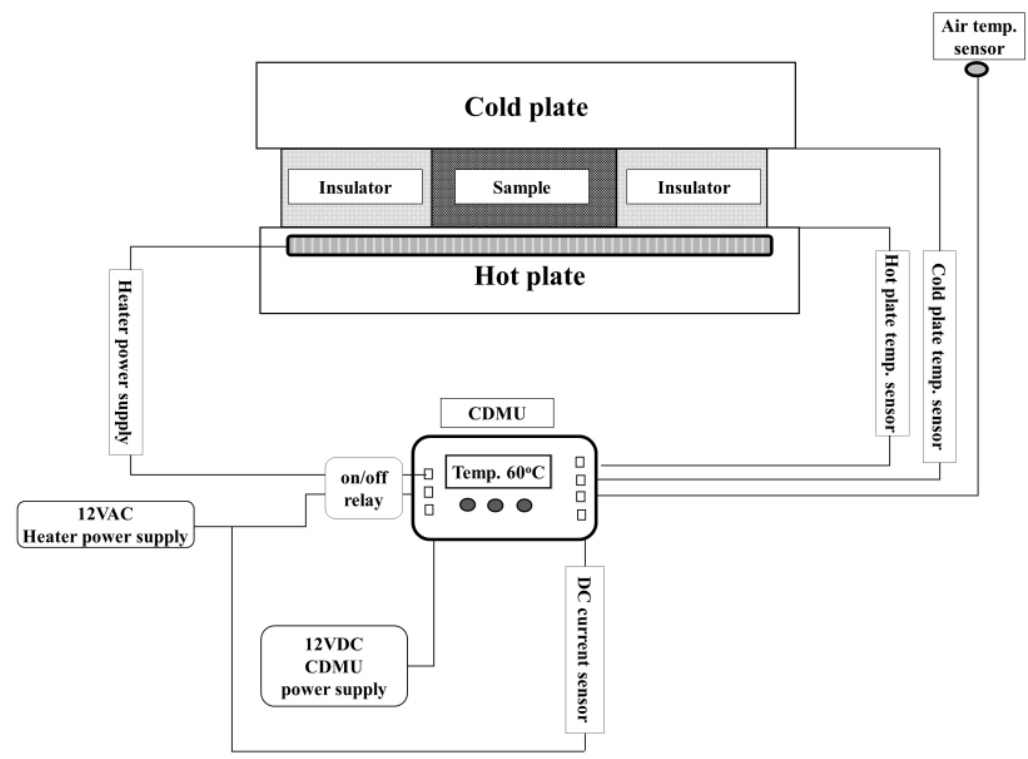

Fig. 2. Schematic of instrument used in a thermal conductivity measurements system.

\subsubsection{Scanning electron microscope analyses (SEM)}

Electron micrograph of different CTLS gypsum composite were captured at the Laboratory of the Faculty of Science, Alexandria University by using scanning electron microscopy (SEM) of JEOL model JSM-5300 at accelerating voltage of $25 \mathrm{kV}$.

\subsubsection{Bulk density of CTLS-gypsum composite}

A set of samples of dimensions $4 \mathrm{~cm} \times 4 \mathrm{~cm} \times 16 \mathrm{~cm}$ were used to determine hardened composite bulk density. Three samples of each mixture were tested after removing from the mold up to 28 days. All 
samples were dried at $105 \pm 5^{\circ} \mathrm{C}$ until reached a constant weight and then were placed in the room condition to cool down.

The weight and the volume based on the three basic dimensions of each dried specimen were measured. The bulk density was determined using equation (4) as follows:

$$
D=W_{d} / V
$$

Where, $D$ is the bulk density of the sample $\left(\mathrm{g} / \mathrm{cm}^{3}\right), W_{d}$ is the weight of the dry sample $(\mathrm{g})$, and $V$ is the volume of the sample $\left(\mathrm{cm}^{3}\right)$.

\section{RESULTS AND DISCUSSION:}

\section{Chrome tanned leather shaving (CTLS) characteristics}

The chemical properties of collected CTLS were determined and the results are shown in Table (3). The obtained values of chemical characteristics were expected due to the similarity between CTLS and the ordinary chrome tanned leathers in chemical properties, which are in agreement with the literature (Sethuraman et al., 2013; Putshaka, et al. 2015 and Abebaw and Abate, 2018). Regarding the high protein content (TKN 12.66\%) and the low fat content $(0.29 \%)$ of CTLS, it is due to remove flesh, fats and globular proteins from pelts in beamhouse, before tanning, to purify collagen fibers from other filling materials (Dutta, 2008). Thus, CTLS consists mainly of collagen fibers, which are produced as a residue of shaving machine when adjusting leather thickness (BASF, 2007).

Table 3: Characteristics of chrome tanned leather shaving

\begin{tabular}{lcc}
\hline \multicolumn{1}{c}{ Parameter } & ASTM & Value \\
\hline Moisture content & D-6403 & $10.24 \%$ \\
Ash content & D-2617 & $12.37 \%$ \\
Chromium content & D-6714 & $2.51 \%$ \\
Fat content & D-3495 & $0.29 \%$ \\
Total Kjeldahl Nitrogen (TKN) & D-2868 & $12.66 \%$ \\
pH Value & D-2810 & $3.32 \mathrm{ml} \mathrm{mol/L}$ \\
\hline
\end{tabular}

Scanning electron micrographs at 1500x and 5000x of CTLS show the fibrous structure aspects (Figure 3). The collagen fibers shown cemented as bundles due to chromium crosslinks of tanning reaction, which led to the presence of separation spaces among fiber bundles. 

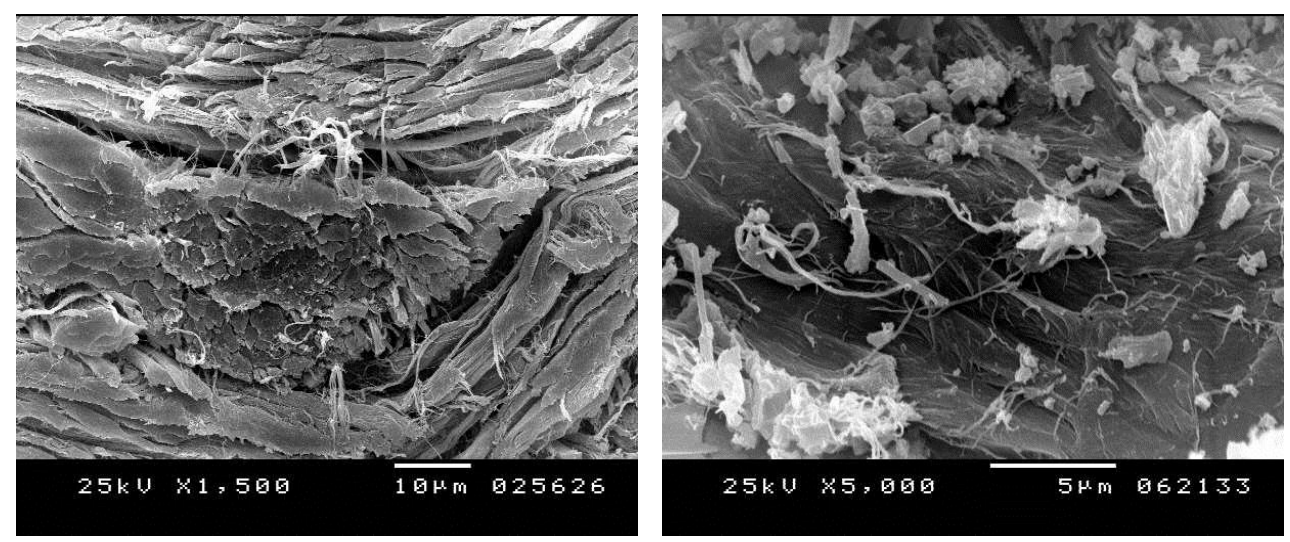

Fig. 3. Electron micrograph of chrome tanned leather shaving at 1500x (left) and 5000x (right)

\section{Characteristics CTLS-gypsum composite}

\subsection{Variation of CTLS-gypsum composite density}

Variation of density for different CTLS-gypsum composite specimens is shown in Figure (4). From obtained results, it was noticed that different factors are affecting the density values of the CTLS-gypsum composite. The density was inversely affected by the increase in the CTLS content. It was expected due to low density of CTLS as a result of presence air gaps among collagen fibers and each other, as well as among CTLS and gypsum, which are shown in scanning electron micrographs (Figures 3 and 5). Also, the density was inversely affected by increase the specimen's age, which might be due to the decreasing of the specimen's weight as a result of the loss of water by time. Therefore, the time required for stabilizing the weight of the specimen was increased by increasing CTLS content, which was not exceed 7 days for all gypsum composites containing CTLS with percentages from $0 \%$ to $25 \%$. On the other hand, density values decreased from 2.03 to $1.33 \mathrm{t} / \mathrm{m}^{3}$ at 1 day, from 1.99 to $1.21 \mathrm{t} / \mathrm{m}^{3}$ at 3 days, from 1.95 to $1.16 \mathrm{t} / \mathrm{m}^{3}$ at 7 days, and from 1.94 to $1.15 \mathrm{t} / \mathrm{m}^{3}$ at 28 days due to increasing the CTLS content from $0 \%$ to $25 \%$. The trend of density and adding CTLS was determined previously in other investigations by Lakrafli et al. (2012), Sathish and Vijayaravind (2015) and Reddy et al. (2016), which was similar with the obtained trend in this study. 


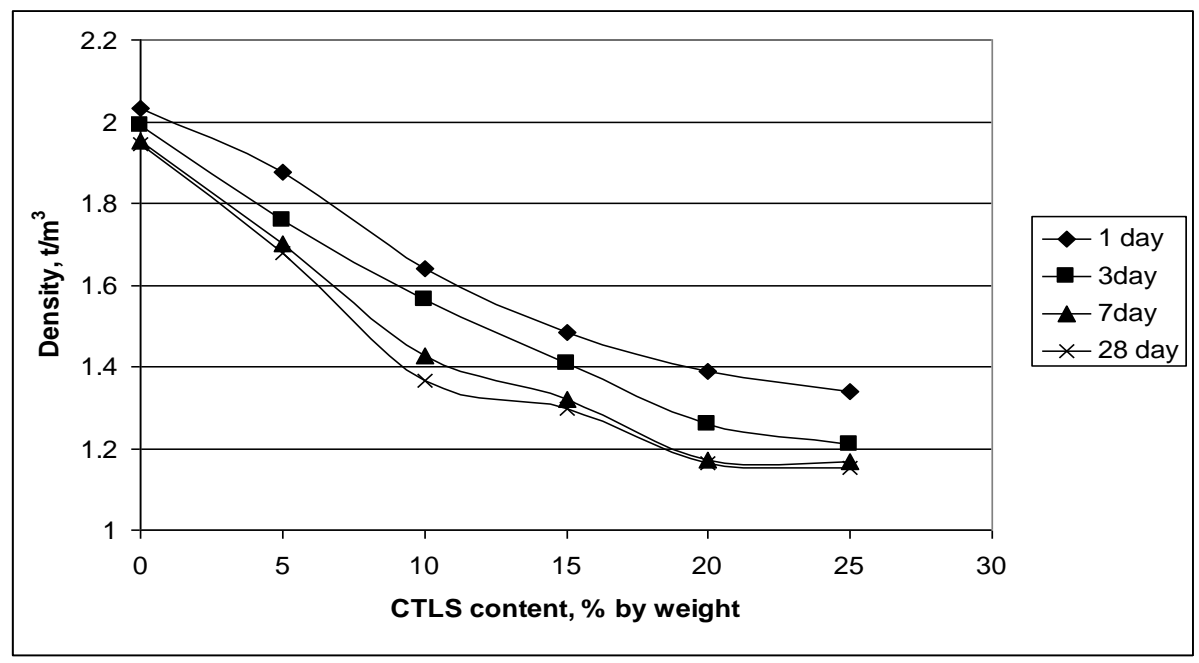

Fig. 4. Variation of density for different CTLS-gypsum composite specimens

\subsection{Micrograph of CTLS gypsum composite}

The scanning electron micrographs of different CTLS-gypsum composite are shows in Figure (5). The addition of CTLS to gypsum composite was led to increase collecting the crystal needles of gypsum, as well as, the volume of crystal needles tended to be higher in volume by CTLS addition, which was observed in micrographs at magnification 5000x. In addition, the lower magnification at 1500x shows that the CTLS particles are homogeneously distributed and complex structured, which show as fully covered with crystal needles of gypsum. This indicates a strong binding between gypsum and CTLS fibers.

\subsection{Effect of CTLS content on mechanical strength}

Mechanical strength was determined for all tested specimens at room condition. Figures (6) and (7) show the variation of compressive and flexural strengths for different CTLS-gypsum composite specimens at three ages; 1,7 and 28 days. Results showed that compression and flexural values increased by increasing specimens' age. It was also observed that by increasing the CTLS percentage, both compressive and flexural values decreased. Thus, the values of compressive and flexural strengths were the highest when no CTLS was added, while adding CTLS to gypsum decreased the compressive and flexural strengths. 


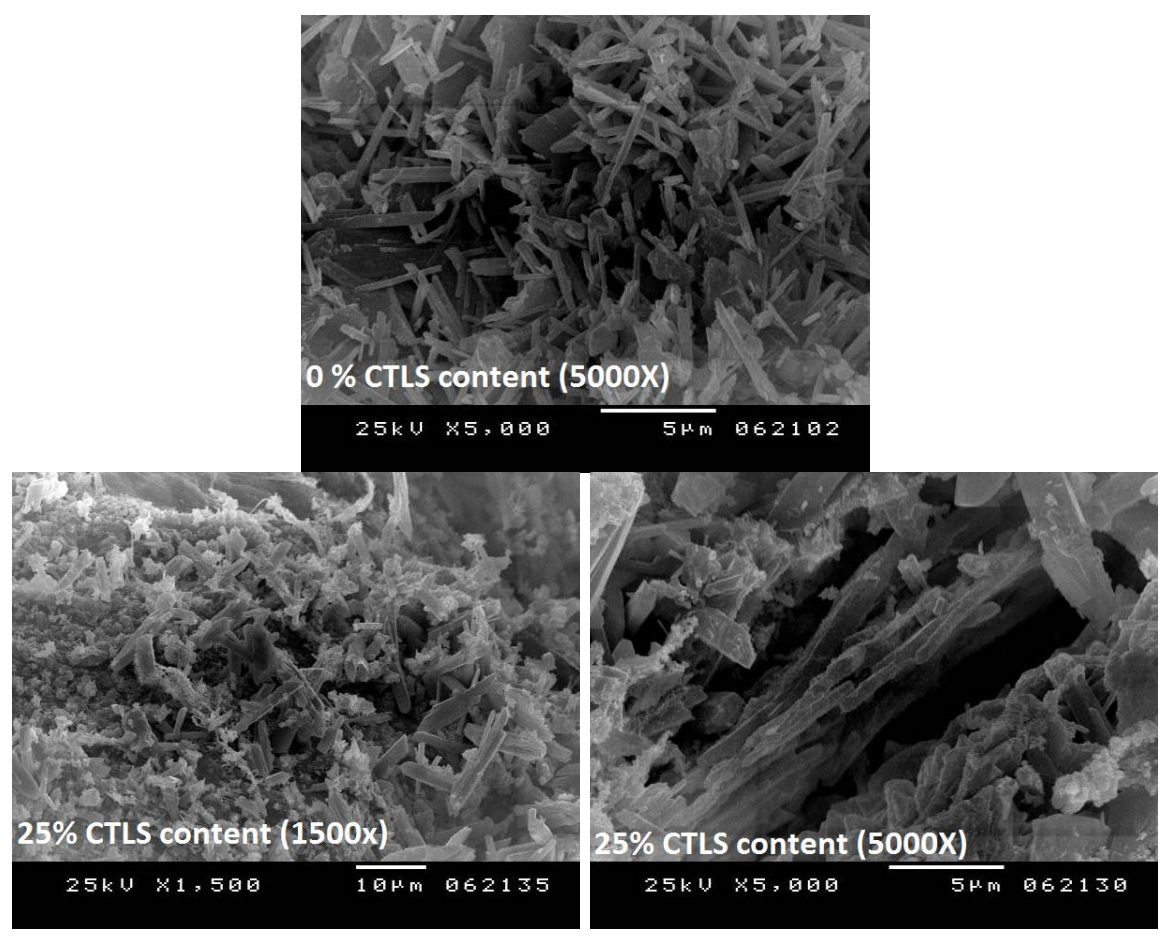

Fig. 5. Scanning electron micrographs of CTLS-gypsum composite This might be explained due to the additional porosity induced by CTLS fibers, as well as, the porous nature of CTLS. Similar trends were found by previous investigators by adding CTLS to cement composites and concrete (Abuh and Umoh, 2015, Reddy et al., 2016, Zhu et al., 2018 and Selamat et al., 2019).

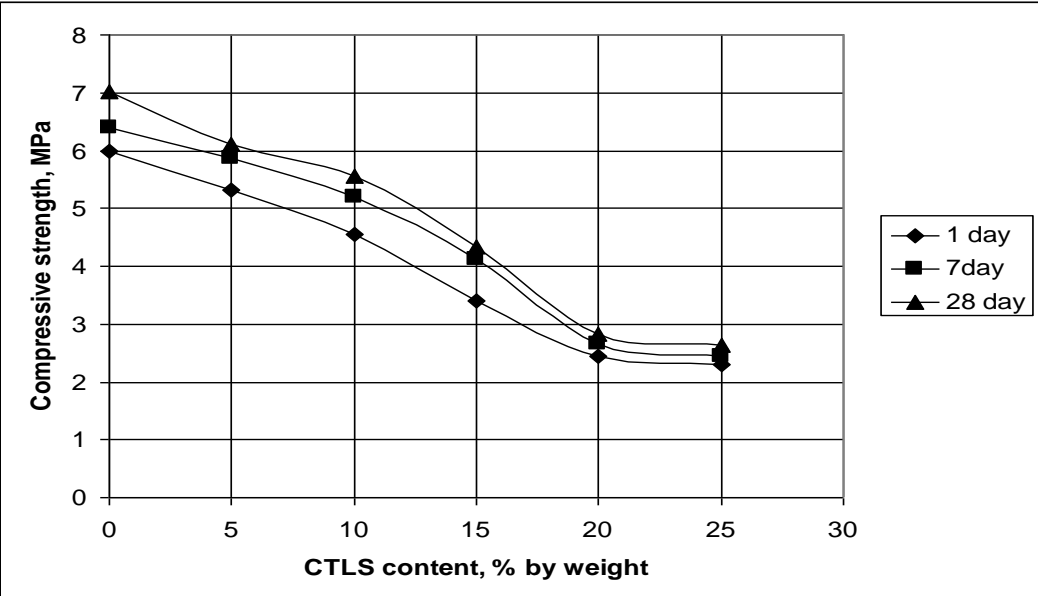

Fig. 6. Variation of compressive strength for different CTLS-gypsum composite specimens 


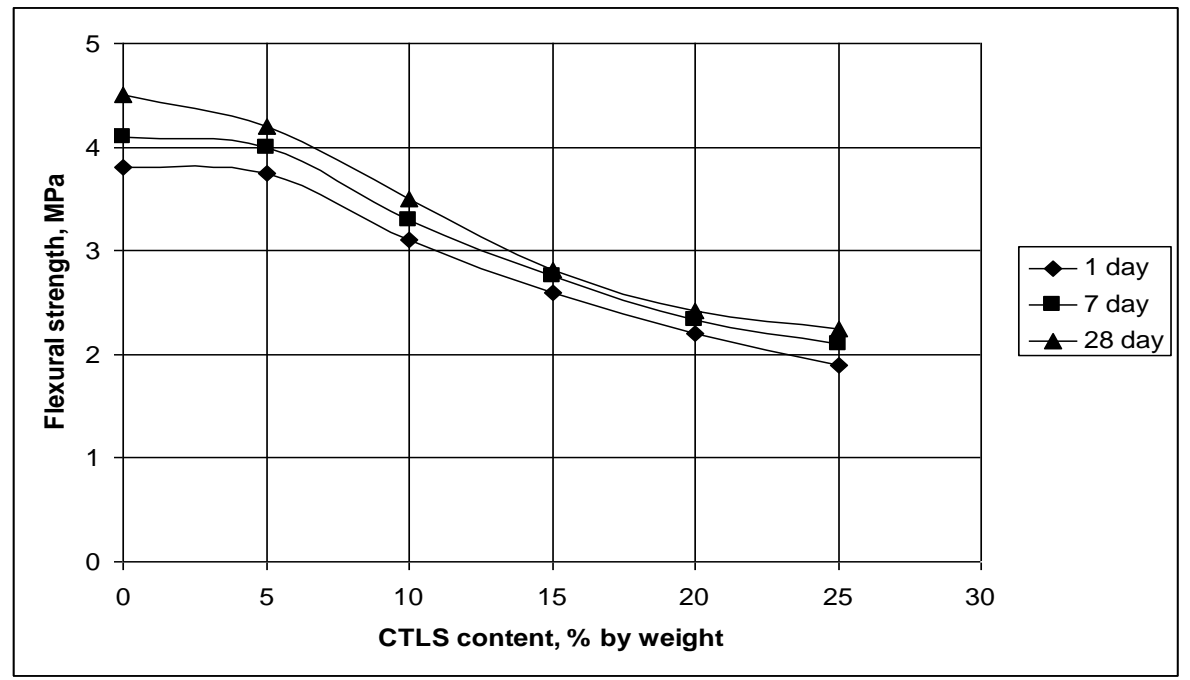

Fig. 7. Variation of flexural strength for different CTLS-gypsum composite specimens

\subsection{Effect of CTLS content on thermal conductivity}

Behavior of adding CTLS in gypsum composites on thermal conductivity shows in Figure (8). Values of thermal conductivity were decreased from 0.6 to $0.19 \mathrm{~W} / \mathrm{m}{ }^{\circ} \mathrm{C}$ by increasing CTLS content from $0 \%$ to $25 \%$, respectively. On the other hand, it means that increasing the percentage of CTLS in the composite will increase the thermal resistance and can be used as thermal isolations.

The relation between thermal conductivity and the percentage of CTLS in gypsum composites is affected negatively, which was expected as aforementioned due to the decrease in density by increasing the percentage of CTLS (Figure 4).

The relation between thermal conductivity and density of CTLS-gypsum composites is shown in Figure (9). Moreover, the thermal conductivity variations of different gypsum composites specimens were approximately similar to their density variations (Figures 4 and 8). These results are in agreement with previous investigations, when adding similar wastes, such as lignocellulosic materials, to gypsum or cement composites (Abuh and Umoh, 2015, Reddy et al., 2016, Zhu et al., 2018 and Selamat et al., 2019). 


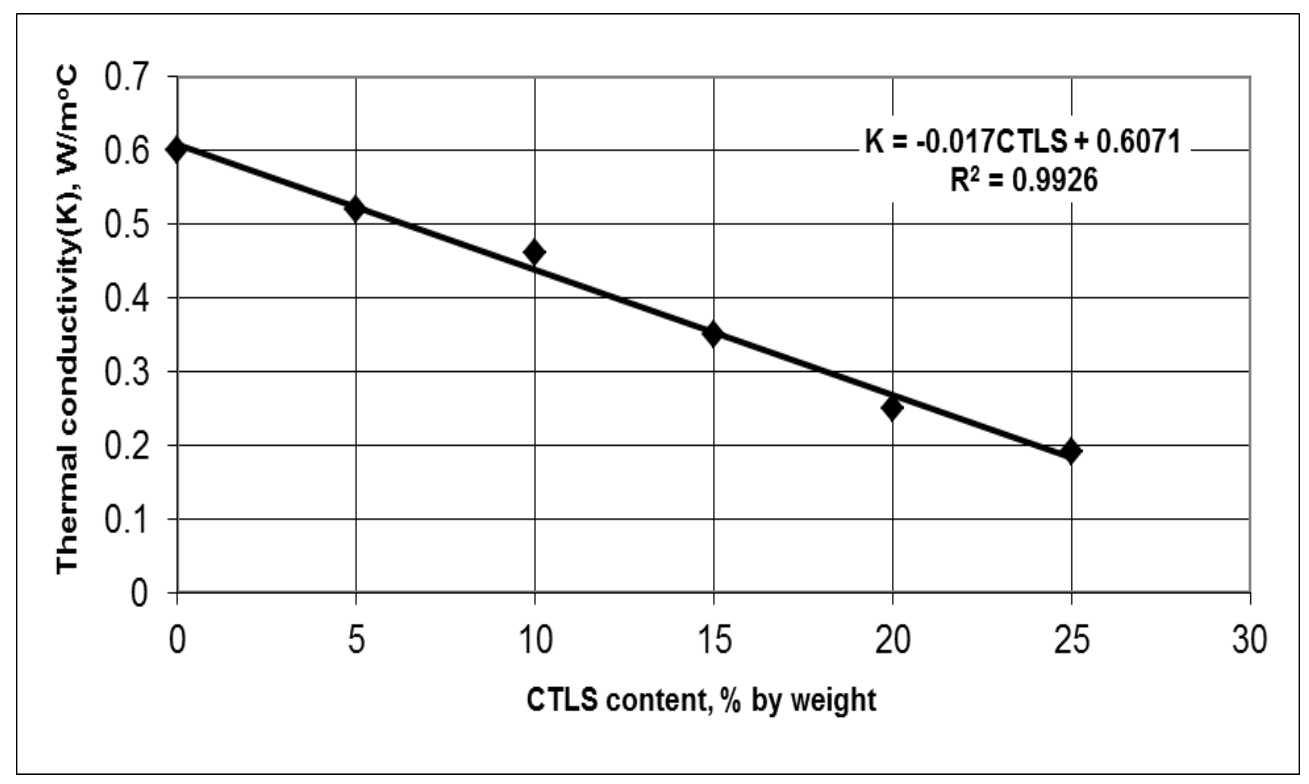

Fig. 8. Relation between thermal conductivity and CTLS content in gypsum composite

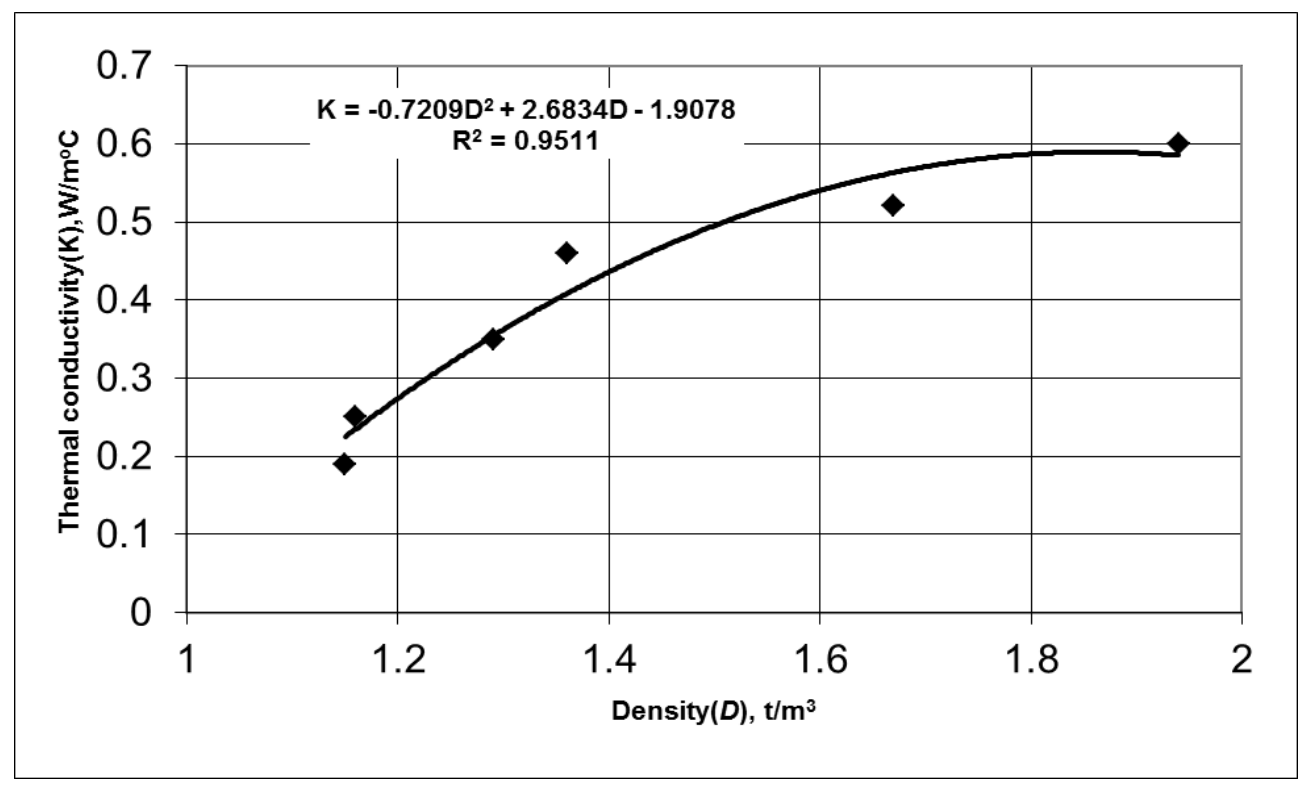

Fig. 9. Relation between thermal conductivity and density of experimental CTLS-gypsum composite 


\section{CONCLUSION}

The results of the current study pointed out the efficiency of utilizing chrome tanned leather wastes, as unused globally industry waste, in gypsum composite for improving the properties of gypsum composite and achieving distinctive environmental and economic benefits. Additionally, the results showed that while adding chrome tanned leather wastes to gypsum composite increases the void gaps among gypsum particles, it enhances collecting crystal needles of gypsum on chrome tanned leather wastes fibers. This change in structure led to decreasing mechanical strength, density and thermal conductivity, which can be used as thermal isolation in many applications such as cold storage when no high compressive strength is required.

Consequently, using chrome tanned leather wastes as insulator material is a good solution to increase energy insulation and thus reduce the loss in energy as well as resolve the problems of handling leather industry waste. Finally, further investigations will be needed in order to utilize chrome shaving wastes for producing successful manufacture construction gypsum board.

\section{REFERENCES}

Abebaw, G., and B. Abate. "Chrome tanned leather waste dechroming optimization for potential poultry feed additive source: a waste to resources approach feed for future." J. of Environ. Pollut. amd Manag 1, no. 1 (2018): 1-6.

Abuh N., and Umoh A. "Palm kernel fruit fiber reinforced gypsumcement based wall panels: it's physical and mechanical characteristics." Pollution Vol. 1 Issue 02 (2015) :117-126.

Agrawal, A., and V. : B.D., P. Kumar. "Remediation options for the treatment of electroplating and leather tanning effluent containing chromium-a review." Miner Process Extra Metal Rev 27 (2006): 99-130.

ASTM. Books of standards Vol.15.04. USA: American Society for Testing and Materials, 2014. 
Bank, World. Pollution Prevention and Abatement-Hand Book. Washington, DC, USA., 1999.

BASF. Pocket book for leather technologist. 4. 67056 Ludwigshafen, Germany: Badische Anilin- und Soda-Fabrik, 2007.

DIN EN 196-1, 2005. Methods of testing cement - Part 1: Determination of strength", Beuth Verlag, Berlin.

Dutta, S.S. An Introduction to the Principles of Leather Manufacture. 4. India: Indian Leather Techno Association, 2008.

Eylem, K.: Rita, P., and F.I.P. Pere. "Composites from leather industry buffing dust: a review." Annals of the University of Oradea Fascicle of Textiles, Leatherwork 18, no. 2 (2017): 149-154.

FAOSTAT. Production-Crops data. ROME: World Food And Agriculture Organization, 2017.

Giovannoni, Elena, and Giacomo Fabietti. "Chapter 2: What Is Sustainability? A Review of the Concept and Its Applications." In Intgerated reporting concepts and cases that redefine corporate accountability, by C. Busco, M.L. Frigo, A. Riccaboni, \& P. Quattrone, 21-40. Springer International Publishing, 2013.

Gudro, Ilze. "Opportunities of Raw Hide Using as a Sustainable Material in Latvia." Scientific Journal of Riga Technical University 3 (2011): 103-107.

Husen, Ahmed, Alebachew Tilahun, Ayichew Teshale, and Tadele Gashaw. "Review on Pre and Post- Slaughter Defects of Hide and Skin in Ethiopia." Advances in Biological Research 10, no. 3 (2016): 154-161.

Kolomaznik, K., M. Mladek, F. Langmaier, D.C. Shelly, and M.M. Taylor. "Closed loop for chromium in tannery operation." $\mathrm{J} \mathrm{Am}$ Leather Chem Assoc 98, no. 12 (2003): 487-490.

Lakrafli H., S. Tahiri , A. Albizane and M.E. El Otmani. "Effect of wet blue chrome shaving and buffing dust of leather industry on the thermal conductivity of cement and plaster based materials". Construction and Building Materials 30(2012): 590-596. 
Pati, A., R. Chaudhary, and S. Subramani. "A review on management of chrome-tanned leather shavings: a holistic paradigm to combat the environmental issues." Environ Sci Pollut Res 21 (2014): 1126611282.

Ponsubbiah, S., S. Suryanarayana, and D. Sanjeev Gupta. "Composite from Leather Waste." IJLTEMAS 7, no. 3 (2018): 77-80.

Putshaka, D.J., A. Yakubu, A., M. Jauro, and M. H.H. and Kolo. "Effect of alkali and acid concentration in extraction of chromium III from tannery solid waste." American Journal of Chemistry and Application 2, no. 6 (2015): 89-94.

Reddy M. V., K. Ashalatha, and K. Sasi. "Partial Replacement of Fine Aggregate by Tannery Shredded Waste in Concrete." Saudi Journal of Engineering and Technology. Vol-1, Iss-4(2016):149-151.

Saravanabhavan, S., K.J. Sreeram, J.R. Rao, and B.U. Nair. "The three pot solution for chromium, tannins and solid wastes: recovery and reuse technique for spent semi chrome liquor and chrome shaving." J Soc Leather Technol Chem 89 (2005): 111-114.

Sathish Kumar V and Vijayaravind S. "Utilization of Tannery Shredded Waste as Fine Aggregate in Concrete. "International Journal of Engineering Research \& Technology. Vol. 4 Issue 04, (2015):484486.

Selamat M., R. Hashim, O. Sulaiman, M. Kassim, N. Saharudin, O. Taiwo. "Comparative study of oil palm trunk and rice husk as fillers in gypsum composite for building material. " Construction and Building Materials. Vol. 197 (2019) :526-532.

Sethuraman, C., K. Srinivas, and G. Sekaran. "Double pyrolysis of chrome tanned leather solid waste for safe disposal and products recovery." Int J Sci Eng Res 4, no. 11 (2013): 61-67.

Tahiri, S., et al. "Thermal behaviour of chrome shavings and of sludges recovered after digestion of tanned solid wastes with calcium hydroxide." Waste Manag 27 (2007): 89-95.

Zhu et al., "Physical and mechanical properties of gypsum-based composites reinforced with PVA and PP fibers. " Constr. Build. Mater. Vol.163 (2018): 695-705. 


\section{الملخص العربى}

\section{الخصائص الهندسية لخليط الجبس ومخلفات حلاقة الجلود المدبوغة بالكروم}

\section{محمد إبراهيم نصر مرسي' و أحمد إبراهيم نصر׳}

تنتج صناعه دباغه الجلود كميات كبيره من المخلفات الجلدية الصلبة. وتقدر مخلفات الحلاقة

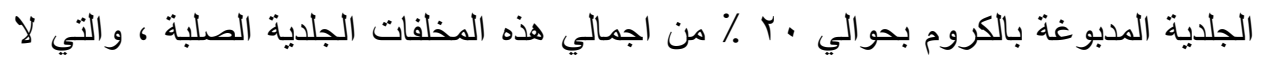
تستغل في مصر مما يجعلها تسبب مخاطر بيئية وخسائر اقتصادية. تهدف هذا البحث الي دراسة

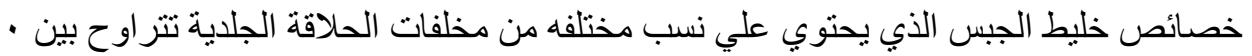

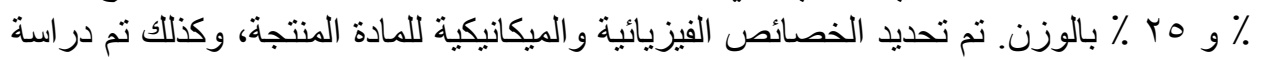
طبيعة التر ابط بين الجبس و المخلف المستخدم بإستخدام المبكرسكوب الاليكتروني. وقد أظهرت

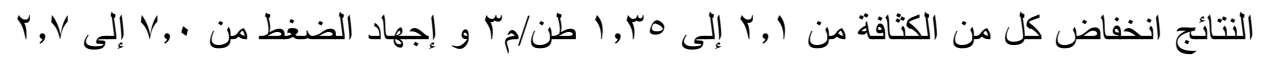

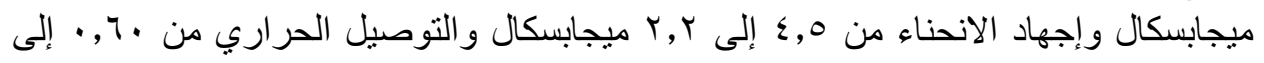

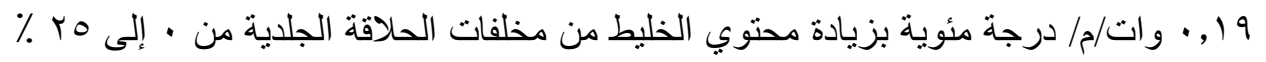

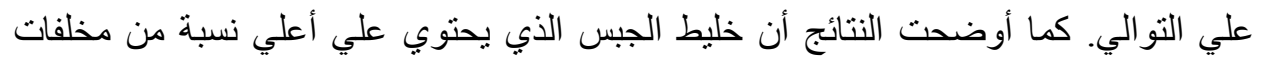

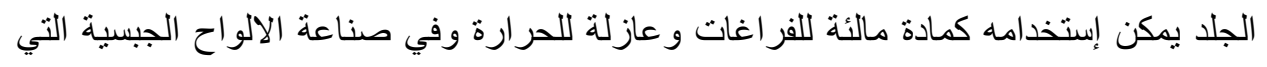

تستخدم في التطبيقات الداخلية للمباني وصناعة ثلاجات حفظ وتخزين الحاصلات الزر اعية.

1 ـ مدرس بقسم الهندسة الزراعية و النظم الحيوية ـ كلية الزراعة - جامعة الإسكندرية - مصر. r ـ أستاذ باحث مساعد إنتاج وتكنولوجيا الجلود ـ مركز بحوث الصحر اءـ المطرية ـ القاهرة - مصر. 